\title{
Opportunities for the production and economics of Virginia fanpetals (Sida hermaphrodita)
}

\author{
Erika Kurucz ${ }^{1}$, Miklós G. Fári ${ }^{1}$, Gabriella Antal ${ }^{1,2}$, Zoltán Gabnai ${ }^{2} *$, József Popp ${ }^{2}$ and Attila \\ $\mathrm{Bai}^{2}$ \\ ${ }^{1}$ Faculty of Agricultural and Food Sciences and Environmental Management, University of \\ Debrecen, Hungary \\ ${ }^{2}$ Faculty of Economics and Business, University of Debrecen, Hungary. \\ * Correspondence: gabnai.zoltan@econ.unideb.hu; Tel.: +36-52-508-444/86902
}

\begin{abstract}
The main goal of this paper is to analyse the efficiency of the plantlet production of Virginia fanpetals, to make economic calculations for their energetic use and to determine the most favourable plant density. According to the experiments, the cost of a healthy Sida plantlet is in the range of 38.4 - 60.6 Euro cents, using the nurse-in-tray technology (NIT). This cost range is much lower than the market prices of the plantlets and the production method is more reliable compared to sowing. In the second year, the dry matter yield originating from Sida plantlets was 10.2-11.9 $\mathrm{t}_{\text {hectare }}{ }^{-1}$ (ha) without fertilization in the different planting densities. However, in the longer term, it is recommended to apply organic manure regardless of spacing. The theoretical market value of Sida is generally higher than total unit costs (36- 60 EUR $\mathrm{t}^{-1}$ ) in the case of all methods used, except for biogas. The production of Sida can be economical for farmers farming in marginal conditions, using locally available organic manure, producing crops with high heat demand, or involved in beekeeping.
\end{abstract}

Keywords: Sida hermaphrodita, plantlet production, economics, bioenergy

\section{Introduction}

Global population growth coupled with changes in dietary habits will increase food demand, resulting in a shift in the utilisation of arable land to direct and indirect (meat and dairy production) food production. The production of third generation, i.e., biogeneration crops (e.g. algae) is a possible solution due to the energy use of first and second generation energy crops (maize, sorghum, etc.), as well as their unfavourable impact on food prices, arable land structure, water management and biodiversity [1,2]. It is one of the main characteristics of these crops that the main objective of their genetic improvement with biotechnological tools is to be able to provide high biomass yields, even on marginal lands [3]. Theoretically, it would be possible to produce $25-30 \%$ of the world's liquid fuel demand in marginal areas [4]. Converting conventional crop areas to energy crop production leads to seasonally differentiated land use patterns for conventional crops [5], and field level profitability can also be improved [6]. As energy crops are new to farmers, and thus have certain risks associated with their cultivation, as well with securing both contracts and market prices, for a successful uptake it is vital they provide a reasonable income [7]. According to the analyses of Dombi et al (2014), the most important elements of sustainability are land demand and social impacts (employment, revenue production) [8].

The primary aim of this research is to examine the production technology of Virginia fanpetals based on technical literature sources and the authors' experimental data, as well as an economic analysis of Sida production in Hungary. In the experiments extensive 
agrotechnical solutions were used - without fertilisation - to analyse the crop nutrition ability of calcareous chernozem soil with low nutrient supply ( $\mathrm{pH}$ : 7.93 \pm 0.025 ; humus content: $3.14 \% \pm 0.407, \mathrm{CaCO}_{3}: 4.67 \pm 0.00, \mathrm{NH}_{4}: 0.15 \mathrm{mg} \mathrm{kg}^{-1}, \mathrm{NO}_{3}: 0.08 \mathrm{mg} \mathrm{kg}^{-1}$, Organic N: $0.14 \mathrm{mg}$ $\mathrm{kg}^{-1} \mathrm{~K}_{2} \mathrm{O}: 465.0 \pm 7.071, \mathrm{P}_{2} \mathrm{O}_{5}: 24.76 \pm 0.692 \mathrm{mg} \mathrm{kg}^{-1}$ ), for the production of $S$. hermaphrodita. A relatively large spacing was used in small plot experiments in order to try to mitigate the soil depletion caused by crops. Furthermore, the profitability of the novel method was examined, as well. In addition to the various methods of heat energy production, biogas and honey production, as well as $\mathrm{CO}_{2}$ saving are also taken into consideration.

\subsection{Production characteristics}

Sida has the potential to be a multi-purpose perennial semi-shrub plant of the temperate climate zone. This species is indigenous in North America, where it is an endangered species [9]. Virginia fanpetals is most effectively propagated vegetatively, as its root section is rich in buds, while sexual propagation is difficult due to the low and protracted germination of seeds, as well as the slow initial growth of the seedling [10-12]. Flowering begins in early summer (early June in Hungary) and it lasts until late October, which is favourable if the crop stand is used as bee pasture. Further favourable characteristics of Virginia fanpetals are that it is less sensitive to $\mathrm{pH}$ [13], and it already provides a significant yield in its second year of production [14].

If sexual propagation is used, it is necessary to increase the germination capacity of Sida, which is between 10 and $15 \%$ in the case of 1-2-year-old seeds $[11,12,15]$. Germination is further complicated by endogenous fungal diseases and the water impermeable coat of the seeds $[10,16,17]$. These considerations make two-step seed priming necessary before sowing, as this method completely eliminates contaminated seeds and the exogenous pathogenic fungal diseases of seeds, resulting in a potential germination percentage above $70 \%$ [18].

Sowing can be performed with S071/B KRUK, a one-by-one pneumatic seeder used in maize sowing, which has an appropriate efficiency and a proportion of skips below 22\% [19]. However, plant density is not ideal and the percentage of duplicated plants is high. Considering the slow and uneven initial development of Sida seedlings, their sensitivity to weeds and potentially to chemical weed control [20], seeding is not reliable, while yield can only be expected following the third year; furthermore, the crop protection activities which need to be performed are quite costly. The required amount of sowing seed is between $2-6 \mathrm{~kg}$ per hectare [11].

Plantlet production is potentially favourable from many perspectives:

- The problematic initial increase and the several hundred-fold demand for sowing seed can be eliminated [21].

- Wide row spacing makes it possible to perform inter-row tillage, which is a more favourable method of weed control, considering the aspects of soil protection and the sensitivity of Virginia fanpetals to chemicals, as herbicides which have proved to be effective have an unfavourable impact on the enzyme activity of soils [22, 23]. On the other hand, the biomass yield can be increased with higher planting densities under normal soil conditions in Central Europe (Austria) by using mineral fertilizer [24].

- In addition to using contamination-free propagation material (seed or plantlet) against fungal diseases, chemical weed control can also be provided. However, in dense populations, the number of spray applications needs to be increased to 2-3 occasions 
in a given growing season. In the case of wide plant density, the number of spray applications can be reduced to one per year [11].

Based on a comparative analysis, focusing on the biomass yield of 36 different energy crops, it can be concluded that Virginia fanpetals belongs to the upper third of energy crops, with its 15 tons of dry matter yield per hectare [25]. Taking into consideration the fact that it is very suitable for soil remediation and the use of extensive production technology, this yield can be regarded as favourable. Furthermore, other studies have found that Sida biomass production intercropping with legumes and using digestate fertilization under marginal conditions can result in higher biomass production and lower environmental pressure in the temperate zone (Germany) [26, 27]. Studies from Lithuania have reported the advanced effect of liming with $\mathrm{N}$ fertilization on the biomass yield of Sida [28, 29].

In comparison with other similar crops which have a high biomass yield (such as willow or miscanthus), Sida extracts nutrients from the soil to a proportionately lower extent, since some of these nutrients are returned into the soil by means of the roots and fallen leaves of the crop. Harvesting performed in the proper time results in a low ash content and a relatively low level of extracted mineral substance content [30].

In the case of proper nutrient replenishment, Sida provides high biomass yield quantity (6.819.6 $\mathrm{t}$ absolute dry matter per hectare $\left.\left(\mathrm{DM} \mathrm{t} \mathrm{ha}^{-1}\right)\right)$ with a high heating value (17.5-19.9 MJ $\mathrm{kg}^{-1}$ ) [11, 31-34] (Table 1).

Table 1. S. hermaphrodita yields at different fertilisation levels.

\begin{tabular}{|c|c|c|c|c|c|c|c|c|c|c|c|}
\hline \multirow[t]{2}{*}{$\begin{array}{c}\text { Sour- } \\
\text { ce }\end{array}$} & \multirow[t]{2}{*}{$\begin{array}{l}\text { Propa- } \\
\text { gation } \\
\text { materi- } \\
\text { al } \\
\end{array}$} & \multirow[t]{2}{*}{$\begin{array}{c}\text { Plant } \\
\text { density } \\
\text { crop } \\
\text { m }^{-2} \\
\end{array}$} & \multicolumn{5}{|c|}{$\begin{array}{l}\text { Dry biomass production } \\
\mathrm{kg} \mathrm{ha}^{-1}\end{array}$} & \multirow[t]{2}{*}{$\begin{array}{l}\text { Heating } \\
\text { value } \\
\mathrm{MJ} \mathrm{kg}^{-1}\end{array}$} & \multirow[t]{2}{*}{$\begin{array}{c}\mathbf{N} \\
\mathbf{K g}^{-1} \\
\mathbf{h a}^{-1}\end{array}$} & \multirow[t]{2}{*}{$\begin{array}{c}\mathbf{P} \\
\mathbf{K g} \\
\mathbf{h a}^{-1}\end{array}$} & \multirow[t]{2}{*}{$\begin{array}{c}\mathbf{K} \\
\mathbf{K g} \\
\mathbf{h a}^{-1}\end{array}$} \\
\hline & & & $\begin{array}{c}\text { Year } \\
1\end{array}$ & $\begin{array}{c}\text { Year } \\
2\end{array}$ & $\begin{array}{c}\text { Year } \\
3\end{array}$ & $\begin{array}{c}\text { Year } \\
4\end{array}$ & $\begin{array}{l}\text { Ave- } \\
\text { rage }\end{array}$ & & & & \\
\hline [33] & seeds & $\begin{array}{c}25 \\
\text { seeds }\end{array}$ & $\begin{array}{c}2 \\
790\end{array}$ & 8360 & 11080 & 11300 & 8382 & 19.8 & $\begin{array}{l}100- \\
200\end{array}$ & $\begin{array}{l}39.3- \\
52.4\end{array}$ & 83 \\
\hline [32] & seeds & $\begin{array}{c}25 \\
\text { seeds }\end{array}$ & n.d. & 11240 & 10760 & 15010 & 12337 & 18.8 & 100 & 35 & 83 \\
\hline [32] & $\begin{array}{l}\text { root } \\
\text { cuttings }\end{array}$ & 4.08 & n.d. & 15310 & 20750 & 22630 & 19563 & 18.7 & 100 & 35 & 83 \\
\hline [11] & seeds & $3 \mathrm{~kg}$ & n.d. & 9440 & 14410 & 11930 & 11927 & $17.5-19.5$ & n.d. & n.d. & n.d. \\
\hline [11] & seeds & $6 \mathrm{~kg}$ & n.d. & 11680 & 15950 & 13820 & 13817 & $17.5-19.6$ & n.d. & n.d. & n.d. \\
\hline [11] & seeds & $9 \mathrm{~kg}$ & n.d. & 13160 & 15840 & 14500 & 14500 & $17.5-19.7$ & n.d. & n.d. & n.d. \\
\hline [11] & $\begin{array}{l}\text { root } \\
\text { cuttings }\end{array}$ & 3.3 & n.d. & 6610 & 10030 & 8320 & 8320 & $17.5-19.8$ & n.d. & n.d. & n.d. \\
\hline [11] & $\begin{array}{c}\text { root } \\
\text { cuttings }\end{array}$ & 5 & n.d. & 7820 & 13810 & 10820 & 10817 & 17.5-19.9 & n.d. & n.d. & n.d. \\
\hline [11] & $\begin{array}{l}\text { root } \\
\text { cuttings }\end{array}$ & 10 & n.d. & 11010 & 17770 & 14390 & 14390 & $\begin{array}{l}17.5- \\
19.10\end{array}$ & n.d. & n.d. & n.d. \\
\hline [35] & $\begin{array}{l}\text { root } \\
\text { cuttings }\end{array}$ & 3.5 & & 11200 & 12200 & 9300 & 10900 & 16.5 & 150 & 43.6 & 125 \\
\hline [35] & $\begin{array}{l}\text { root } \\
\text { cuttings }\end{array}$ & 3.5 & & 9300 & 10900 & 6300 & 8800 & 16.9 & 100 & 26.4 & 66.3 \\
\hline
\end{tabular}

If biomass is intended to be used in its green form, the most appropriate timing is determined by the given crop year. Polish examples refer to three harvesting dates [11]. Based on the experiments performed at the University of Lublin, fertilisation has a favourable impact on the growth of green mass up to the application of $400 \mathrm{~kg} \mathrm{ha}^{-1} \mathrm{~N}$ active ingredient, even though 
it reduces the proportion of certain microelements and amino-acids. The yield of the two harvests ranged between 7.4.-9.53 $\mathrm{t} \mathrm{ha}^{-1}$ of green mass, depending on the fertiliser dose $(\mathrm{N}$ : $100-400 \mathrm{~kg} \mathrm{ha}^{-1} ; \mathrm{K}_{2} \mathrm{O}: 50-150 ; \mathrm{P}_{2} \mathrm{O}_{5}: 80 \mathrm{~kg}$ ) [11]. Based on the research of Jablonowski et al. (2017) conducted in Germany the biomass production method with one harvest yearly for solid fuel has the highest energy balance, accounting for $439288 \mathrm{MJ} \mathrm{ha}^{-1}$, compared to the more biomass harvesting system used with Sida biomass production [36].

There are several alternatives available for harvesting Sida. Mechanisation is the preferred method in the case of harvesting larger areas, as the cost of manual operations is many times higher than the cost of mechanical labour. In addition, harvest of the dried Sida biomass after vegetation allows both a maximum energy yield and a reduced negative impact on the growing plantation, which results in a sustainable supply of Sida biomass over several years $[32,33]$.

Harvesting is either performed in a single or double cut regime. The former can be carried out with forage harvesters used in maize harvesting [11]. Since the moisture content of the Sida stem decreases below $20 \%$ by the end of winter [11], the chopped stem can be left on the field.

\subsection{The effect of Sida on soil reclamation and waste management}

Table 2 summarises the results of soil remediation research. The overwhelming majority of references are therefore of Polish origin, so it seems to be very important to compare them with the experiments of Virginia fanpetals production in Hungary, including results relating to land reclamation and waste management.

Table 2. Results of land reclamation experiments.

\begin{tabular}{|c|c|c|}
\hline Result & Experiment details & Reference \\
\hline \multirow{4}{*}{$\begin{array}{l}\text { Soil reclamation, soil } \\
\text { remediation, phytoremediation. } \\
\text { Heavy metal accumulation and } \\
\text { uptake }\end{array}$} & $\begin{array}{l}\text { Small plot analysis on acidic fields and areas contaminated } \\
\text { with zinc and lead }\end{array}$ & {$[37]$} \\
\hline & $\begin{array}{l}\text { Analysis of } \mathrm{Zn}, \mathrm{Cu} \text { and other heavy metal contamination of } \\
\text { land }(\mathrm{Cu} \text { accumulation: foliage, root system; } \mathrm{Zn} \\
\text { accumulation: foliage })\end{array}$ & {$[38]$} \\
\hline & $\begin{array}{l}\text { Testing the cleansing effect of Virginia fanpetals based } \\
\text { biochar (absorbent) }\end{array}$ & [39] \\
\hline & $\begin{array}{l}\text { Accumulation of harmful substances in the soil (mainly in the } \\
\text { root zone) }\end{array}$ & {$[40]$} \\
\hline $\begin{array}{l}\text { Biomass production, waste } \\
\text { management. Nutrient } \\
\text { utilisation and pollutant } \\
\text { sequestration: increasing crop } \\
\text { yield and macroelement } \\
\text { content, improving uptake } \\
\text { ability and soil life }\end{array}$ & $\begin{array}{l}\text { Sewage sludge and sewage sludge compost application and } \\
\text { their use in agriculture }\end{array}$ & $\begin{array}{l}{[41],[42],} \\
{[43],[44],} \\
{[45],[46],} \\
{[47],[48],} \\
{[49],[50],} \\
{[51],[52],} \\
{[53]}\end{array}$ \\
\hline $\begin{array}{l}\text { Increasing yield and waste } \\
\text { management, } \\
\text { macroelements and pollutant } \\
\text { uptake, }\end{array}$ & $\begin{array}{l}\text { Application of sewage sludge compost and brown coal ash } \\
\text { from power plants }\left(\mathrm{CaCO}: 1.5 \mathrm{Mg} \mathrm{CaO}^{*} \mathrm{ha}^{-1} \text {; High-calcium }\right. \\
\text { brown coal ash: } 1.5 \mathrm{Mg} \mathrm{CaO} * \mathrm{ha}^{-1} \text {; municipal sewage sludge } \\
\text { compost: } 250 \mathrm{~kg} \mathrm{~N} \mathrm{ha}^{-1} \text {; their combination and half-dose }\end{array}$ & $\begin{array}{l}{[54]} \\
{[55]}\end{array}$ \\
\hline
\end{tabular}




\begin{tabular}{|c|c|c|}
\hline $\begin{array}{l}\text { bioassimilation, sewage sludge } \\
\text { application, } \quad \text { significantly } \\
\text { higher } \mathrm{P}, \mathrm{Mg} \text { and } \mathrm{S} \text { content. }\end{array}$ & $\begin{array}{l}\text { experiments); content analyses } \\
\text { Soils saturated with lead and cadmium; application of sewage } \\
\text { sludge and brown coal mixture }\end{array}$ & [56] \\
\hline $\begin{array}{l}\text { Pollutant uptake: accumulation } \\
\text { of } \mathrm{Co}, \mathrm{Fe} \text { and } \mathrm{N} \text { in the stem }\end{array}$ & Production on $0.5 \mathrm{~m}$ thick sewage sludge & [57] \\
\hline $\begin{array}{l}13.8-17.8 \mathrm{DM} \mathrm{t} \mathrm{ha}^{-1} \text { on good } \\
\text { quality soil; } 6.85-11.3 \mathrm{DM} \text { tha } \\
{ }^{1} \text { on sewage sludge substrate } \\
\text { significant heavy metal uptake } \\
\text { in the stem }\end{array}$ & $\begin{array}{l}\text { Yield comparison of different production sites: good quality } \\
\text { soil and sewage sludge substrate. Analysis of the pollutant } \\
\text { uptake of sludge. }\end{array}$ & $\begin{array}{l}{[58],} \\
{[59],}\end{array}$ \\
\hline $\begin{array}{l}\text { Increasing yield and waste } \\
\text { management, } \\
\text { macroelements and pollutant } \\
\text { uptake, nutrient replenishment } \\
\text { and cost saving, soil life } \\
\text { improvement effect; proper } \\
\text { alternative, optimum dose: } 40 \mathrm{t} \\
\mathrm{ha}^{-1}\end{array}$ & $\begin{array}{l}\text { Application of biogas ferment on less favoured, sandy fields } \\
\text { (as an alternative of conventional NPK fertilisation); }\end{array}$ & $\begin{array}{c}{[60,61],} \\
{[62],[63],} \\
{[64],[65],} \\
{[66]}\end{array}$ \\
\hline
\end{tabular}

\subsection{Sida for energy production}

According to the measurements of Szemplinski et al. (2014), the heating value of Virginia fanpetals $\left(18.3 \mathrm{MJ} \mathrm{kg}^{-1}\right)$, the energy gained with different technologies (intensive: $1.81 \mathrm{GJ} \mathrm{t}^{-1}$, semi-intensive: $1.53 \mathrm{GJ} \mathrm{t}^{-1}$ ), as well as their energy efficiency (intensive: 10.2 , semiintensive: 12.6 per dry matter unit: HHV) in the years 2009-2011 [35] exceed the respective values of silo maize or sorghum. At the same time, the average dry matter yield of Sida per hectare was much lower than that of both crops (54\% lower than maize yield and $23 \%$ lower than sorghum yield). With regard to the heating values of Sida, some papers also found an HHV of 18.1 MJ kg1- and an LHV of $16.8 \mathrm{MJ} \mathrm{kg}-1$ [33, 34, 36]. Stolarski et al. (2014) investigated the higher heating value of Sida hermaphrodita and obtained a value of $18.9 \mathrm{MJ}$ kg-1, while Krička et al. (2017) tested an HHV of 17.9 MJ kg-1 [67, 68].

Virginia fanpetals is either directly combusted, or it can be used as an outstanding (supplementary) feedstock for biogas production in accordance with the measurements of Oleszek et al. 2013 [69]. The composition of Sida silage fermented for 40 days under mesophilic circumstances in 2010 was the following:

- $26 \%$ dry matter, $91 \%$ of which was organic matter

- $39 \%$ carbon, $1.7 \%$ nitrogen, (C/N ratio: $22.4 \%), 9.5 \%$ ash

- $\mathrm{pH}: 5.5$

The biogas yield of Sida was quite favourable, both in terms of quantity and quality (Table 3), and this yield can be further increased if the proper formula is followed. The $\mathrm{C} / \mathrm{N}$ ratio is ideal in itself, unlike most animal or vegetable feedstock. The estimated optimum range is $15-30$ [70], 20-30 [71, 72] and 25-30 [73].

Table 3. Biogas and methane yield from Virginia mallow in an anaerobic digestion process (2010).

Biogas yield Methane yield




\begin{tabular}{cccccc}
\hline $\mathrm{Ndm}^{3} \mathrm{~kg}^{-1}$ & $\mathrm{Ndm}^{3} \mathrm{~kg}^{-1}$ & $\mathrm{Ndm}^{3} \mathrm{~kg}^{-1}$ & $\mathrm{Ndm}^{3} \mathrm{~kg}^{-1}$ & $\mathrm{Ndm}^{3} \mathrm{~kg}^{-1}$ & $\mathrm{Ndm}^{3} \mathrm{~kg}^{-1}$ \\
$\mathrm{FM}$ & $\mathrm{DM}$ & $\mathrm{ODM}$ & $\mathrm{FM}$ & $\mathrm{DM}$ & $\mathrm{ODM}$ \\
$99( \pm 3)$ & $395( \pm 11)$ & $435( \pm 12)$ & $50( \pm 1.5)$ & $201( \pm 5.5)$ & $220( \pm 6)$ \\
\hline
\end{tabular}

Source: [69]

The biogas yield of Virginia fanpetals was especially high between days 6 and 12, even reaching 20-60 $\mathrm{Nm}^{3} \mathrm{~kg}^{-1} \mathrm{DM}$.

It is important to emphasise that biogas production calls for much higher moisture content in comparison with combustion. For this reason, Virginia fanpetals for biogas production needs to be harvested in July. As no drying costs are incurred it can be regarded as cost saving and there is no dry matter loss which usually occurs at low temperatures.

\section{Materials and Methods}

\subsection{Production technological experiments}

The University of Debrecen provided a $10000 \mathrm{~m}^{2}$ demonstration garden, half of which was used for mallow and other herbaceous biomass crops and/or ornamental plants, as well as half-wild and field crops used for various purposes. $5 \mathrm{~m}$ wide and $45 \mathrm{~m}$ long cultivated strips were established on the plot with similar grass-covered strips in between. According to preliminary plans, 7 cultivated and 7 grassy block were established. The mildly alkaline (7.93 $\mathrm{pH} \pm 0.025)$ heavy chernozem soil was rich in humus $(3.14 \% \pm 0.407)$ and calcium carbonate $(4.67 \pm 0.00)$. The land quality was not extreme marginal, but we used a low input and very extensive agrotechnology with a low soil nutrient content.

During planting, three relatively wide spacings were used: $1 \mathrm{~m} \times 1 \mathrm{~m}, 1 \mathrm{~m} \times 0.75 \mathrm{~m}$ and $1 \mathrm{~m} \times$ $0.5 \mathrm{~m}$ (Figure 1/A), to demonstrate that crops are able to compensate for the lower plant density used in the case of wide spacing by producing greater growth and more shoots per stem. Consequently, in this way it is possible to determine the best spacing in areas with similar characteristics.

Harvesting was performed with hand tools. The data for the inner stems were used during the biomass yield calculation.

Figure 1. Plants of the Future Demonstration garden at the University of Debrecen (20102015, Hungary)

Source: authors' photos and composition

A: Sida plantation (left to right: $1 \mathrm{~m}$ x $1 \mathrm{~m}, 1 \mathrm{~m}$ x $0.75 \mathrm{~m}, 1 \mathrm{~m}$ x 0.5m (Google Earth);

B: 3-year-old Sida population;

C: Sida population in November;

D: Sida sheaves from a 3-year-old population.

\subsection{Plantlet production experiments}

The technology of plantlet production is described in detail in previously published papers by the authors of this study $[18,74]$; therefore, it is not covered in this research. The nurse-intray technology consists of using single-space units $(595 \times 300 \times 65 \mathrm{~mm}$ (Figure 2/A)) instead of applying the cell-tray method (previous experiments) for plantlet production in unused production units. Following the short plantlet production period, plants are overwintered in 
so-called planting trenches which were established in accordance with field conditions (Figure $2 / \mathrm{C}$ ). Later, these plants can be easily removed from the planting trenches (Figure 2/B-E).

Figure 2. Production of Sida plantlets with the nurse-in-tray method.

Source: authors' photos and composition

A: establishment of the propagation tray,

B: medium interwoven with roots at the time of plant relocation,

C: trays placed in the planting trench (August 2014),

D: the ultra-dense population in late autumn (November 2014),

E: removing the wintered plants from the planting trench (May 2015),

F: whole overwintered plantlet and cut back plantlet with roots.

The nurse-in-tray plantlet production experiment was carried out on two occasions with seed densities of 30-40, and 50-64 per tray $\left(0.18 \mathrm{~m}^{2}\right)$ in the spring of 2014 and 2015 , respectively (between July 2014 and May 2015). Two seeds were placed in the previously established planting holes (Figure 2/A). Since this latter spacing (64 seeds per tray) was shown to be the most favourable, plantlet costs were calculated in accordance with the results of this experiment (Table 4). The efficiency of each work phase of the nurse-in-tray method and the distribution of costs are shown in Table 4. In this experiment, plantlet production was performed with rented equipment, the cost of which is optional.

Table 4. Calculated costs of the nurse-in-tray method, based on the authors' own data.

\begin{tabular}{lccccc}
\hline $\begin{array}{l}\text { Work } \\
\text { phase }\end{array}$ & $\begin{array}{c}\text { Personnel } \\
\text { costs per } \\
\mathbf{1 0 0 0} \\
\text { plantlets } \\
\text { (EUR) }\end{array}$ & $\begin{array}{c}\text { Material } \\
\text { costs per } \\
\mathbf{1 0 0 0} \\
\text { plantlets } \\
\text { (EUR) }\end{array}$ & $\begin{array}{c}\text { Polytunnel } \\
\text { rental costs per } \\
\text { 1000 plantlets } \\
\text { (EUR) }\end{array}$ & $\begin{array}{c}\text { Total cost per } \\
\text { 1000 plants } \\
\text { with planting } \\
\text { (EUR) }\end{array}$ & $\begin{array}{c}\text { Total cost per } \\
\text { 1000 plants } \\
\text { without } \\
\text { planting } \\
\text { (EUR ) }\end{array}$ \\
\hline sowing & 7.95 & 26.17 & 4.32 & 38.45 & \\
$\begin{array}{l}\text { UD } \\
\text { planting }\end{array}$ & 22.11 & & & 22.11 & \\
Total & 30.06 & 26.17 & 4.32 & 60.56 & 38.45 \\
\hline
\end{tabular}

UD: ultra-dense planting (252 plantlets per $\mathrm{m}^{2}$ )

Source: authors' own data and calculations

\subsection{Economic calculations}

The economic calculations focused on the efficiency of each production technology element, as well as the profitability of Sida production with a comparative method.

In the analysis of the production technology, planting was compared to seeding, and fertiliser doses were examined in the light of the extra yield obtained. In the calculations the authors' own results deriving from the extensive plantlet technology were used, while other data were provided by the literature source [27]. Hungarian technical literature sources and databases were used to retrieve the economic data related to the cost of fertilisation, mechanical and manual labour, while sowing seed and plantlet prices were obtained from international technical literature sources/databases. Rental fees (as actual or opportunity costs) were calculated using the Hungarian average (Hungarian Statistical Office, 2016), overhead costs (9\% of direct costs) are based on sector-level data collection and processing from the Farm 
Accountancy Data Network (FADN), Research Institute of Agricultural Economics, Hungary (2016).

In the case of 10,000 and 20,000 plant densities, the yields are the average of the results of the second to the fourth years of the authors' own tests, since the yield of the first year is not relevant in our view, due to the partly balanced population. Costs of planting/sowing were calculated for a 20-year-long life cycle which could be reduced when extensive technology is used. Taxes were not considered as their levels may change significantly depending on the scale and type of operation. Profits from substituted branches as opportunity costs are excluded from our calculations, since they are not accounting costs, and so are not suitable for the calculation of either production costs, nor unit costs, and also because they are hard to predict and depend on plant, year, soil type and technology.

The laboratory heating value was compared to the theoretically expected heating values (which can be estimated with formulas) and the actual heating value was calculated by taking into account the moisture content of the authors' own material sample used in this research. The expected economic value of Sida combusted in a stove was obtained by a calculation based on the price of the most frequently used fuels, their typical heating value and stove efficiency. This can be considered as a theoretical market price of Sida. Given the fact that Sida is a brand new crop it does not have a market price, and so we had no real-world statistics available.

Sida was taken into consideration just as a feedstock for biogas production, as it has become a potential feedstock of biogas plants in operation. The value of natural gas saving was calculated from the expected methane yield, based on literature sources. The stock exchange value of $\mathrm{CO}_{2}$ saving was also considered. The following basic data were used for the calculations:

- biogas yield of Sida: $395 \mathrm{Nm}^{3} \mathrm{t}^{-1}$ Sida DM, of which the quantity of biomethane is 201 $\mathrm{Nm}^{3} \mathrm{t}^{-1}$ Sida DM [69],

- moisture content of Sida: $14 \%$ (average value of authors' own measurements)

- $\mathrm{CO}_{2}$ content of Sida: $175 \mathrm{Nm}^{3} \mathrm{t}^{-1}$ (own estimation)

- $\mathrm{CO}_{2}$ density: $1.965 \mathrm{~kg} \mathrm{dm}^{-3}$ [75]

- Stock exchange price of $\mathrm{CO}_{2}$ saving: 5 EUR t ${ }^{-1} \mathrm{CO}_{2}$ [76]

For pelletizing and briquetting, Virginia fanpetals was accounted as a supplementary feedstock by using the technical and economic parameters of small-scale equipment in operation (capacity: $100 \mathrm{~kg} \mathrm{~h}^{-1}$ ). The extra costs of production were compared to the expected extra revenue. For this reason, the following parameters were used:

- Electricity demand and price: $16.9 \mathrm{~kW}$ and $22.2 \mathrm{~kW}, 0.1 \mathrm{EUR} \mathrm{kWh}^{-1}[77,78]$

- Personnel costs: 3 people employed for 9 months per year for a monthly salary of 500 EUR

- Other costs: expert evaluation

Sida silage is also suitable for microalgae biomass production based on the work of Dębowski et al. (2017). Microalgae biomass consisting of Chlorella sp. and of Scenedesmus sp. was codigested with the silage of Sida in semi-continuous experiments under mesophilic anaerobic conditions. The results showed that mixing of silage of Sida with microalgae biomass ensured a more balanced $\mathrm{C} / \mathrm{N}$ ratio with less inhibition and digester imbalance [79].

Beekeeping may also potentially result in significant revenue (if biogas is produced, the revenue is lower as a result of the previous harvest), mainly for small-scale producers. The 
honey yield was also calculated on the basis of technical literature sources, while for the price Hungarian premium honey prices were considered:
- honey yield:
$120 \mathrm{~kg} \mathrm{ha}^{-1}[80]$
- price of honey:
$10.8 \quad$ EUR kg $^{-1}[81]$

\section{Theory}

Since there is very scarce literature available for Sida, limited mainly to Polish sources reporting production-related experiments, the authors of this paper consider it important to communicate the results of the Hungarian field experiments including economic calculations of production costs and the profit attainable in the case of energy utilization. The purpose of this study is to investigate the production technology of Virginia fanpetals based on technical literature sources, evaluate the efficiency of the plantlet production of Virginia fanpetals by using the authors' experimental data and make economic calculations for Sida production.

The plant health background of the vegetative plantation of Virginia fanpetals is not entirely known, making it a rather risky process. Cuttings cannot be properly maintained either, as they need to be preserved from drying, fungal infections, early emergence and heat damage at the same time [11]. Consequently, propagation from seed is the safest method of establishing the population. The prime cost of the propagation material is of crucial importance for an economical evaluation of the plant.

Based on the calculations of Balezentiene et al. (2013), Sida is one of the most promising crop species in terms of its multi-criteria framework, and as a sustainable choice for energy production [82].

The reason for its high heating value is that its carbon and hydrogen content $(47 \%$ and $6 \%$, respectively) are basically the same as that of Miscanthus ssp. and energy willow, but the nitrogen and ash content $(0.2 \%$ and $1.8 \%$, respectively), which reduce heating value, are much lower than their respective values [83]. Sida is very suitable for biogas production even with its greater moisture content, because its biogas yield is very high (cca. $435 \mathrm{Ndm}^{3} \mathrm{~kg}^{-1}$ $\mathrm{ODM})$ and its $\mathrm{C} / \mathrm{N}$ ratio is very favourable [83].

The value of Sida is greatly dependent on the quality of biomass to be used, the purpose of use and the type of fossil energy source it substitutes. These factors were evaluated with the help of the typical technical parameters and Hungarian economic data for 2015. Our hypothesis is that the high yield and good composition probably make Sida a cheap raw material for heat and biogas production and also of potential interest to bee-keepers.

\section{Results}

\subsection{Efficiency of plantlet production methods}

197-506 plantlets per $\mathrm{m}^{2}$ can be produced with the nurse-in-tray method, which corresponds to large-scale plantlet production (427 plantlets per $\mathrm{m}^{2}$ ). Based on the land rent, the rental rate for a polytunnel for the production of 1000 plantlets is between 4.30 and 17.00 EUR, depending on the plant density per $\mathrm{m}^{2}$. A higher density did not reduce germination; on the contrary, the most favourable germination rate was achieved in the case of the highest plant density (Table 5). 
Table 5. The efficiency of the NIT method and the rental rate of covered production equipment for the production of 1000 plants using various plant densities per tray.

\begin{tabular}{cccccc}
$\begin{array}{c}\text { Number of } \\
\text { sowed } \\
\text { seeds /tray }\end{array}$ & $\begin{array}{c}\text { Germina- } \\
\text { tion rate }\end{array}$ & $\begin{array}{c}\text { Seedling } \\
\text { per } \mathbf{~ m}^{\mathbf{2}}\end{array}$ & $\begin{array}{c}\text { Polytunnel } \\
\text { rent } \\
\boldsymbol{\epsilon}_{\text {per } \mathbf{~ m}^{\mathbf{2}} \text { per }} \\
\text { month }\end{array}$ & $\begin{array}{c}\text { Plantlet } \\
\text { growing time } \\
\text { (day) }\end{array}$ & $\begin{array}{c}\text { Rental cost for } \\
\text { the production } \\
\text { of 1000 } \\
\text { plantlets, } \boldsymbol{€}\end{array}$ \\
\hline $30.00^{1}$ & 59.00 & 196.67 & & & 16.70 \\
$40.00^{1}$ & 64.50 & 286.67 & 2.19 & 32.00 & 11.45 \\
$50.00^{1}$ & 51.80 & 287.78 & & & 11.41 \\
$64.00^{2}$ & 71.20 & 506.31 & & 20.00 & 4.32 \\
\hline
\end{tabular}

: plantlet production in August 2014. ${ }^{2}:$ : plantlet production in May 2015

Source: authors' own tests and calculations

Based on the calculated data, one person is able to produce 177.0-314.5 viable plantlets per hour, depending on the plant density, which amounts to a labour cost of 7.90-14.12 EUR for the production of 1000 plantlets (Table 6). These calculations are based on the most efficient spacing (64 plantlets per tray). In the experiments the total costs of the nursing of a single, healthy, well developed $S$. hermaphrodita plantlet fluctuated between 38.4 and 60.6 Euro cents.

Table 6. Efficiency of labour, calculated for the NIT method.

\begin{tabular}{|c|c|c|c|c|c|}
\hline $\begin{array}{l}\text { Number } \\
\text { of sown } \\
\text { seeds } \\
\text { per tray }\end{array}$ & $\begin{array}{l}\text { Labour } \\
\text { efficiency } \\
\text { tray } \mathbf{h}^{-1}\end{array}$ & $\begin{array}{l}\text { Labour } \\
\text { efficiency } \\
\text { seed } \mathbf{h}^{-1}\end{array}$ & $\begin{array}{c}\text { Loss } \\
(\%)\end{array}$ & $\begin{array}{c}\text { Labour } \\
\text { efficiency } \\
\left(\text { plantlet } \mathbf{h}^{-1}\right)\end{array}$ & $\begin{array}{c}\text { Cost of labour } \\
\text { needed for the } \\
\text { production of } 1000 \\
\text { plantlets, } €\end{array}$ \\
\hline 30 & 5.00 & 300 & $41.0^{\mathrm{a}}$ & 177.0 & 14.12 \\
\hline 40 & 3.75 & 300 & $35.5^{\mathrm{ab}}$ & 193.5 & 12.92 \\
\hline 50 & 3.00 & 300 & $49.2^{\mathrm{a}}$ & 152.4 & 16.40 \\
\hline $64^{*}$ & 3.50 & 448.00 & $29.8^{\mathrm{b}}$ & 314.5 & 7.95 \\
\hline
\end{tabular}

Wage: $2.5 € \mathrm{~h}^{-1}$. Different letters mean that there are significant differences between the characteristics measured at the level of $\alpha=0.05$ based on the TUKEY test.

Source: authors' own data and calculations

\subsection{Estimated yield of Sida hermaphrodita}

The non-fertilised Sida population is expected to give a dry biomass yield ranging between 10 $228 \mathrm{~kg} \mathrm{ha}^{-1}$ (13 300 plants per hectare) and $11871 \mathrm{~kg} \mathrm{ha}^{-1}$ (20000 plants per hectare). It was observed that the soil exhaustion effect of higher plant density (20 000 plants per hectare) became increasingly intensive over time. For double plant density, the average yield was nearly identical in the second and third years, while wide spacing resulted in a more balanced population in subsequent years. In the fourth year, wider spacing resulted in a $9384 \mathrm{~kg} \mathrm{ha}{ }^{-1}$ yield, on average (Table 7).

Table 7. Calculated average yield of Virginia fanpetals based on the average weight of inner stems.

\begin{tabular}{ccccccc}
\hline Years & $\mathbf{2 0 1 1}$ & \multicolumn{3}{c}{$\mathbf{2 0 1 2}$} \\
\hline Spacing - thousand plants & 10 & 13.3 & 20 & 10 & 13.3 & 20 \\
per ha & & & & & & \\
Average weight of inner & $299.6 \pm$ & $295.2 \pm$ & 195.4 & $1120.87 \pm 93$ & $769.06 \pm$ & $593.55 \pm$ \\
stems & 56.2 & 53.04 & \pm 034.4 & .3 & 94.4 & 98.4
\end{tabular}




\begin{tabular}{|c|c|c|c|c|c|c|}
\hline $\begin{array}{l}\text { Average yield kg ha-1 } \\
\text { Moisture content } \%\end{array}$ & $2996^{\mathrm{a}, \mathrm{a}}$ & $\begin{array}{l}3926^{\mathrm{a}, \mathrm{a}} \\
14.75\end{array}$ & $3909^{\mathrm{a}, \mathrm{a}}$ & $11208^{\mathrm{b}, \mathrm{a}}$ & $\begin{array}{c}10229^{\mathrm{b}, \mathrm{a}} \\
18.23\end{array}$ & $11871^{\mathrm{b}, \mathrm{a}}$ \\
\hline Years & & 2013 & & & 2014 & \\
\hline $\begin{array}{c}\text { Spacing - thousand plants } \\
\text { per ha }\end{array}$ & 10 & 13.3 & 20 & 10 & 13.3 & 20 \\
\hline Average mass of inner stems & $\begin{array}{c}1076.3 \pm 110 \\
.8\end{array}$ & $\begin{array}{c}678.3 \pm 237 \\
7\end{array}$ & $\begin{array}{c}523.1 \pm 290 \\
8\end{array}$ & $\begin{array}{c}938.4 \pm \\
484.3\end{array}$ & $\begin{array}{c}426.57 \pm \\
175.6\end{array}$ & $\begin{array}{c}358.2 \pm \\
214.8\end{array}$ \\
\hline Average yield kg ha ${ }^{-1}$ & $10764^{\mathrm{b}, \mathrm{a}}$ & $9022^{\mathrm{b}, \mathrm{a}}$ & $10464^{\mathrm{b}, \mathrm{a}}$ & $9384^{\mathrm{c}, \mathrm{a}}$ & $5673^{\mathrm{c}, \mathrm{a}}$ & $7164^{\mathrm{c}, \mathrm{a}}$ \\
\hline Moisture content \% & & 12.64 & & & 10.53 & \\
\hline
\end{tabular}

Different letters on the left side mean that there are significant differences between the years analysed at the level of $\mathrm{a}=0.05$, but no significant differences between the different plant density values (right letters) based on the Tukey test.

Source: authors' own experimental data

In order to use Sida for combustion purposes, it is necessary to know the higher heating value (HHV) of dry matter, for which an average of three literature data sources were used (Table $8)$.

Table 8. HHV of Sida hermaphrodita / Virginia fanpetals based on technical literature data and theoretical calculations.

\begin{tabular}{lcccccccc}
\hline & C & H & O & S & N & Ash & HHV (GJ/DM) & Source \\
\hline & & & & & & & 18.75 & {$[33]$} \\
\% & 47 & 6 & 44 & 0.03 & 0.2 & 1.8 & 18.30 & {$[83]$} \\
Heating value & 16.450 & 7.080 & 4.400 & 0.003 & 0.004 & 0.036 & $\mathbf{1 9 . 1 0 *}$ & {$[84]$} \\
Average & & & & & & & $\mathbf{1 8 . 7 1}$ & \\
\hline
\end{tabular}

*: Calculation of HHV based on the content parameters of the latter source and Gaur and Reed's equation $(1995)\left(\mathrm{HHV}=0.35 \mathrm{X}_{\mathrm{C}}+1.18 \mathrm{X}_{\mathrm{H}}-0.10 \mathrm{X}_{\mathrm{O}}+0.02 \mathrm{X}_{\mathrm{S}}-0.10 \mathrm{X}_{\mathrm{N}}-0.02 \mathrm{X}_{\mathrm{ash}}\right)$

The average moisture content of the samples harvested was $14.04 \%$ in the four years examined, of which the low heating value at harvesting was calculated as follows: LHV = (HHV x (1-M)) - (P x M), where M: moisture content, P: heat of vaporisation of water, LHV: low heating value, $\mathrm{HHV}$ : high heating value $)=16.1 \mathrm{GJ} \mathrm{t}^{-1}$.

Honey also represents added value, the yield of which could even reach $143 \mathrm{~kg} \mathrm{t}^{-1}$ per hectare during flowering between late June and October, if quality parameters are favourable [80]. The value of this product is 144 EUR/ha based on an average Hungarian market price for acacia honey (10.8 EUR t-1).

\subsection{Economic calculations}

The extra cost of planting is quite significant (2-3.5 EUR t-1) at a lower plant density and with extensive technology, while its production risk is much lower than that of sowing. In the case of very significant plant density (40 000 plants $\mathrm{ha}^{-1}$ ) and intensive technology, the difference is negligible in favour of planting (0.6 EUR t-1). The production cost of the more safely planted Sida increased to its highest level $\left(3.5\right.$ EUR t $\left.^{-1}\right)$ with a lower plant density in extensive conditions and with higher plant density in intensive production circumstances as regards the length of the production period (20 years) (Table 9). Production and unit costs are lowest when using the extensive technology of low plant density with plant sowing; therefore, this technology is recommended. This is especially true in the case of purchased sowing seeds, as the difference in costs between sowing and planting seems to be insignificant due to 
the much higher price of market seed. The least recommended version is the middle planting density using semi-intensive technology.

Table 9. Economic differences between planting and sowing in relation to planting density.

\begin{tabular}{|l|c|c|c|}
\hline & $10000 \mathrm{pcs} / \mathrm{ha}^{*}$ & $20000 \mathrm{pcs} / \mathrm{ha}^{*}$ & $40000 \mathrm{pcs} / \mathrm{ha}^{* *}$ \\
\hline Average yield (t DM ha-1) & 9.0 & 8.4 & 20 \\
\hline Cost of planting EUR ha-1 & 1565 & 2170 & 3382 \\
\hline Cost of sowing EUR ha-1 & 929 & 1828 & 3625 \\
\hline Fertilization EUR ha-1 & 0 & 0 & 140 \\
\hline Plant protection EUR ha-1 & 78 & 156 & 156 \\
\hline Harvesting EUR ha-1 & 51.6 & 51.6 & 51.6 \\
\hline Rental fee EUR ha-1 & 145 & 145 & 145 \\
\hline Overhead costs EUR ha-1 & 30 & 41 & 60 \\
\hline Total cost of planting EUR ha-1 & $\mathbf{3 8 3}$ & $\mathbf{5 0 2}$ & $\mathbf{7 2 2}$ \\
\hline Total cost of sowing EUR ha-1 & $\mathbf{3 5 1}$ & $\mathbf{4 8 5}$ & $\mathbf{7 3 4}$ \\
\hline Difference (\%) & 9 & 4 & -2 \\
\hline Difference EUR ha-1 yr-1 & 32 & 17 & -12 \\
\hline Unit cost of Sida (planting) EUR t- & $\mathbf{4 2 . 6}$ & $\mathbf{5 9 . 6}$ & $\mathbf{3 6 . 1}$ \\
\hline 1 & & & $\mathbf{3 6 . 7}$ \\
\hline Unit cost of Sida (sowing) EUR t-1 & $\mathbf{3 9 . 1}$ & $\mathbf{5 7 . 6}$ & -0.6 \\
\hline Difference EUR t-1 & 3.5 & 2.0 & \\
\hline Source:
\end{tabular}

Source: *authors' own experimental data, ** Borkowska and Molas (2012) [32] production data and authors' own costs

Virginia fanpetals can be combusted or gasified without any further processing if we substitute other energy sources for heating. We considered the burning of Sida in a stove which is suitable for burning firewood and can be found a typical village household, and we used its efficiency value for our calculations. The above example produces a value of 67-146 EUR $\mathrm{t}^{-1}$, where the lowest savings occur as a result of substituting straw and the highest are related to pellets (Table 10).

Table 10. Cost of processing the dry biomass of Virginia fanpetals.

\begin{tabular}{lccccccc}
\hline & $\begin{array}{c}\text { Price } \\
\mathbf{( 1 0 0 0} \\
\text { HUF } \\
\text { per } \\
\text { unit) }\end{array}$ & $\begin{array}{c}\text { Heating } \\
\text { value (GJ } \\
\text { per unit) }\end{array}$ & $\begin{array}{c}\text { HUF } \\
\text { per } \\
\text { GJ }\end{array}$ & $\begin{array}{c}\text { EUR } \\
\text { per } \\
\text { GJ }\end{array}$ & $\begin{array}{c}\text { Stove } \\
\text { efficiency } \\
\text { compared } \\
\text { with fossil fuel }\end{array}$ & $\begin{array}{c}\text { Stove } \\
\text { efficiency } \\
\text { Sida }\end{array}$ & $\begin{array}{c}\text { Sida } \\
\text { theoretical } \\
\text { market } \\
\text { price EUR } \\
\text { per t }\end{array}$ \\
\hline Natural gas (1) & 100 & 34 & 2941 & 9.3 & 0.9 & 0.8 & $\mathbf{1 3 1}$ \\
Pellet (2) & 71 & 21 & 3381 & 10.7 & 0.93 & 0.8 & $\mathbf{1 4 6}$ \\
Briquette (3) & 56 & 19 & 2947 & 9.4 & 0.85 & 0.8 & $\mathbf{1 3 9}$ \\
Straw (4) & 15 & 12 & 1250 & 4.0 & 0.75 & 0.8 & $\mathbf{6 7}$ \\
Firewood (5) & 28 & 14 & 2000 & 6.3 & 0.8 & 0.8 & $\mathbf{1 0 0}$ \\
\hline Sources & & & & & \\
\hline
\end{tabular}

Sources of basic data: 1: [71], 2:[77]:, 3:[76]:, 4:[85], 5:[86], exchange rate: 315 HUF/EUR (www.mnb.hu) 
The value of biogas produced from Sida was $55 \mathrm{EUR} \mathrm{t}^{-1} \mathrm{DM}$, which can be further increased by the possible sales of $\mathrm{CO}_{2}$ savings ( $2 \mathrm{EUR} \mathrm{t}^{-1}$ Sida $\left.\mathrm{DM}\right)$. In addition, Sida can be used with higher moisture content for biogas production.

The factors analysed can be taken into consideration for local use (with no transport costs). At the same time, they are many times higher than the production costs of Sida when considering any technology or substituted fuel. Ideally (in the case of combustion by substituting pellets), $2400 \mathrm{EUR} \mathrm{t}^{-1}$ can be realised with direct combustion and intensive technology per hectare, while the respective value of extensive technology was $1107 \mathrm{EUR} \mathrm{t}^{-1}$, which is higher than that of most field crops produced on high quality land.

The production of compressed products (pellets and briquettes), for which increasing market demand can be observed, calls for significant investment costs of around 12 080-12 400 EUR at a production scale of $100 \mathrm{~kg} \mathrm{~h}^{-1}$ (Table 11).

Table 11. Investment costs for the production of compressed Sida products.

\begin{tabular}{|c|c|c|c|c|c|c|}
\hline & \multicolumn{3}{|c|}{ Pellet } & \multicolumn{3}{|c|}{ Briquette } \\
\hline & $\begin{array}{c}\text { Price } \\
(\text { EUR) (1) }\end{array}$ & $\begin{array}{c}\text { Operation } \\
\text { time }(y r) \\
(2)\end{array}$ & $\begin{array}{l}\text { Depreciation } \\
\text { (EUR) }\end{array}$ & $\begin{array}{c}\text { Price } \\
\text { (EUR) } \\
(3)\end{array}$ & $\begin{array}{c}\text { Operation } \\
\text { time }(y r) \\
(2)\end{array}$ & $\begin{array}{c}\text { Depreciation } \\
\text { (EUR) } \\
\text { (4) }\end{array}$ \\
\hline Press & 1850 & 3 & 617 & 5500 & 3 & 1833 \\
\hline Matrix & 130 & 1 & 130 & & & \\
\hline $\begin{array}{l}\text { Cooling } \\
\text { system }\end{array}$ & 3200 & 20 & 160 & & & \\
\hline Drier & 6000 & 20 & 300 & 6000 & 20 & 300 \\
\hline Shredder & 900 & 10 & 90 & 900 & 10 & 90 \\
\hline Total cost & 12080 & & 1297 & 12400 & & 2223 \\
\hline
\end{tabular}

Source: (1): [77] (2): expert opinion, (3): [87] (4): [85]

The extra processing cost of pelleting in 2015 is around $101 \mathrm{EUR} \mathrm{t}^{-1}$, while that of briquetting is 111 EUR t $^{-1}$ per year, in addition to the cost of feedstock production (Table 12). The total cost of producing pellets and biobriquettes from Sida (including raw material costs) is 137161 EUR t-1 and 147-171 EUR t-1, respectively, depending on the production technology used.

Considering the market prices of pellets (215 EUR $\left.\mathrm{t}^{-1}\right)$ and briquettes (178 EUR $\mathrm{t}^{-1}$ ), profit can still be realised, although at much lower level compared to the local use of Virginia fanpetals. However, the return on invested capital in an optimal case can still be expected within 2-3 years.

Table 12. Compression cost of $S$. hermaphrodita (without feedstock costs).

\begin{tabular}{lcc}
\hline & Pellet & Briquette \\
\hline Depreciation, EUR per year & 1297 & 2223 \\
Electricity, EUR per year (1) & 3380 & 4440 \\
Personnel, EUR per year (2) & 13500 & 13500 \\
Other costs, EUR per year (3) & 2000 & 2000
\end{tabular}


Source (1): $16.9 \mathrm{~kW}$ and $22.2 \mathrm{~kW}, 0.1 \mathrm{EUR} / \mathrm{kWh}[77,78]$ (2): 3 persons, 9 month/year employment, $500 \mathrm{EUR} / \mathrm{month}$ salary (3): expert opinion

The main characteristics of S. hermaphrodita are summarised in Table 13, based on our own tests and experiments.

Table 13. The main advantages and disadvantages of industrial scale production of Sida.

\begin{tabular}{|c|c|c|}
\hline & Advantage & Disadvantage \\
\hline $\begin{array}{l}\text { Industrial scale, } \\
\text { cost effective } \\
\text { propagation } \\
\text { technology }\end{array}$ & $\begin{array}{l}\text { Sida plantlet cost was 38.4-60.6 Euro } \\
\text { cents with the NIT method. This } \\
\text { technology is also easily acceptable in } \\
\text { industrial- and small scale production, } \\
\text { and as a result of this technology the } \\
\text { plantation can be established safely. }\end{array}$ & $\begin{array}{l}\text { The plantlet production needs a } \\
\text { polytunnel or a greenhouse. The } \\
\text { rental fees or investment costs } \\
\text { fluctuate depending on the } \\
\text { conditions prevailing in a given } \\
\text { country. }\end{array}$ \\
\hline $\begin{array}{l}\text { Plantation } \\
\text { establishment }\end{array}$ & $\begin{array}{l}\text { The plantation establishment can be } \\
\text { carried out with a traditional planting } \\
\text { machine/ transplanter. } \\
\text { The maintenance of the plantation also } \\
\text { does not require any special machines. }\end{array}$ & $\begin{array}{l}\text { The use of seeds needs further } \\
\text { innovative mechanization. }\end{array}$ \\
\hline $\begin{array}{l}\text { Multipurpose } \\
\text { utilization }\end{array}$ & $\begin{array}{l}\text { Sida can be used as a biomass plant, a } \\
\text { fodder crop and for honey production. } \\
\text { The seeds' high crude oil- and protein } \\
\text { content make them suitable for food, } \\
\text { feed or cosmetic purposes }\end{array}$ & Further studies are needed. \\
\hline $\begin{array}{l}\text { Post-harvest } \\
\text { (Processing) }\end{array}$ & $\begin{array}{l}\text { Because of the low moisture content of } \\
\text { the biomass at the end of the season, } \\
\text { additional drying is not required if the } \\
\text { product is used for combustion. }\end{array}$ & \multirow{2}{*}{$\begin{array}{l}\text { The costs of post-harvest } \\
\text { processing (biogas production, } \\
\text { pelleting etc.) considerably } \\
\text { reduce the expected profit. }\end{array}$} \\
\hline Profitability & $\begin{array}{l}\text { Based on our calculations, the expected } \\
\text { profit was } 63-846 € \mathrm{ha}^{-1}\left(7-94 € \mathrm{t}^{-1}\right) \\
\text { depending on the technology used. } \\
\text { Additionally, honey production can } \\
\text { produce a profit of } 15.40-20.20 €(144 \\
\left.€ \mathrm{t}^{-1}\right) \text { per hectare. }\end{array}$ & \\
\hline $\begin{array}{l}\text { Environmental } \\
\text { impacts }\end{array}$ & $\begin{array}{l}\text { In addition to the favourable } \\
\text { environmental impacts of biomass } \\
\text { plants in general, many literature } \\
\text { sources report that Sida can recultivate } \\
\text { polluted land. }\end{array}$ & $\begin{array}{l}\text { Sida has some polyphagous } \\
\text { phytopathogen } \\
\text { (Sclerotinia sp., Fusarium sp, } \\
\text { Rhizoctonia sp.), which can } \\
\text { survive in the plant's vegetative } \\
\text { remains (stems, roots). }\end{array}$ \\
\hline
\end{tabular}

Source: authors' composition, based on their own tests and results 


\section{Discussion}

\subsection{Efficiency of plantlet production methods}

This experiment verified the authors' previous hypothesis that the nurse-in-tray plantlet production and unprotected wintering (Nurse in Tray Method) of Virginia fanpetals with properly pre-treated seeds can be developed into an economical and safe new propagation method. Plantlet production can be performed near large-scale plots with low investment costs (38.4-60.6 Euro cents per plantlet) based on the calculated data. Firstly, there are no heating costs, and this phytotechnique can be easily and appropriately mechanized. Secondly, with this method, it is possible to produce plantlets with a hardened and strong root system. Furthermore, such plantlets can be planted easily with typical planting equipment. In addition, the large-scale transportation of plantlets can be flexibly adjusted and the planting can even be carried out over almost the entire year. The maintenance costs of the so-called UD (ultradense) planting are insignificant. The propagation material needed for 1 ha can be produced on a very small plot $\left(70 \mathrm{~m}^{2}\right)$, while a high plant density prevents weeds from growing.

\subsection{Estimated yield of Sida hermaphrodita}

In the second year, a yield of 10.2 - 11.8 $\mathrm{DM} \mathrm{ha}^{-1}$ was achieved without fertilisation by using extensive technology. This value falls within the yield range referred to in bibliographical sources. The soil exhaustion impact of a higher plant density (20000 plants per hectare) was increasingly noticeable in years following planting. At the same time, the yield obtained with a plant density of 10000 plants per hectare remained basically unchanged in the three subsequent years. In addition, the wide spacing can make it easier to control weeds mechanically in the early vegetative period of Virginia fanpetals. However, when using extensive technology, organic manure application is recommended in order to provide longterm maintenance. Several studies have highlighted the tolerance of Sida to soils contaminated with heavy metals or treated with sewage sludge, so Sida can play a significant role in the reclamation of contaminated soils with a high organic matter content. Also, Virginia fanpetals plantations are appropriate locations for disposing of sewage sludge produced in large volumes. With regard to fertilization, the digested manure was obtained from a commercially operating biogas plant using maize silage as feedstock, providing an opportunity for sustainable soil management. Instead of using organic substance mineral fertilizers digested manure may increase the yields and contribute to carbon sequestration in soil, but the high energy consumption for the feedstock production has an overall adverse effect. Moreover, Krzyżaniak et al. (2018) suggest that using fertilizers in general at a rate equivalent to $170 \mathrm{~kg} \mathrm{ha}^{-1} \mathrm{~N}$ may not be justified because of a high impact on freshwater eutrophication and acidification [88].

\subsection{Economic calculations}

The calculated cost of the production of an extra ton of yield with fertilisation is around 13.8 EUR. For this reason, high quality land fertilisation could also be economically justified in the dosage (218 kg ha ${ }^{-1} \mathrm{NPK}$ ) reported by Borkowska et al. [32], if the other factors of intensive technology are also provided. As is shown in the experiments, the use of local organic manure (mainly wastewater and sewage sludge) is much more justified on marginal land, in order to decrease the pressure on prime cropland for food security reasons. 
According to the authors' economic calculations, the production cost of Sida over a 20-year life cycle fluctuated between 36 and $60 \mathrm{EUR} \mathrm{t}^{-1} \mathrm{DM}$, depending on the production technology used.

For some additional cost, planting made yields much safer with both extensive and semiintensive technology. At the same time, revenue exceeded production costs in all scenarios, excluding the semi-intensive production of Sida technology for biogas production. The expected profits are the following:

- combustion: 70-94 EUR t $\mathrm{t}^{-1}$

- biogas: (-)6-(+)18 EUR t $\mathrm{t}^{-1}\left(+2 \mathrm{EUR} \mathrm{t}^{-1} \mathrm{CO}_{2}\right.$ value)

- pelleting: 54-78 EUR t ${ }^{-1}$

- briquetting: 7-31 EUR t ${ }^{-1}$

- honey production: $144 \mathrm{EUR} \mathrm{t}^{-1}$ (if it is used for any other purpose)

According to this study, the production cost of Virginia fanpetals was between 36 and 60 EUR $\mathrm{t}^{-1}$ in Hungarian economic conditions. Based on Polish data, the structure of the direct production cost of Sida can be broken down as follows: seedlings 28.2\%; plant protection 1\%; chemicals $12.4 \%$, mechanized methods $35.7 \%$; human labour $3.7 \%$ [89]. Our experiments are similar, but labour is included in the related working operations, and we considered the rental fee of land - which, at $20-40 \%$ is a very significant cost element - as a direct cost.

The profitability of Sida plantations is moderate compared to other energy crops, due to the more unfavourable production conditions. In 2009, the total amount of these potential revenues on surveyed plantations of willow amounted to $107 € / \mathrm{ha} /$ year, while for miscanthus the figure was 171-202 €/ha/year and for Sida hermaphrodita 79-92 € /ha/year without payments and subsidies in Poland [89].

\section{Conclusions}

In accordance with the experiments, the cost of nurse-in-tray technology seems to be significantly cheaper, (38.4-60.6 Euro cent) compared to market plantlet prices. In addition, nurse-in-tray technology proved to be more reliable than sowing.

Based on the calculated biomass production of different dense plantations, the soil depletion impact of higher plant densities (13 300 and 20000 plants per hectare) was increasingly evident; consequently, the biomass production decreased considerably (from 10.2 and $11.9 \mathrm{t}$ ha-1 to 5.6 and $7.2 \mathrm{t}$ ha-1) in the years following planting. At the same time, the yield obtained with a plant density of 10000 plants per hectare decreased only slightly (11.2 and 9.4 t ha-1) in the three years studied. Accordingly, with extensive technology, a wide plant density is recommended, although land fertilization could also be economically justified at a sufficient dosage and in the appropriate form.

Overall, the agrotechnology applied (production method, plant density and inputs used, in particular fertilization) basically determines the production cost of Sida, while the substituted energy source for heating determines the savings by substituting other energy sources and the capital requirement, and thus producing the economic results. These can result in a production cost difference of up to 20,000 HUF / tonne. 
Based on this study's economic calculations, the production costs of Sida plantation over a 20 year life cycle are significantly lower than the revenue they produce under Hungarian economic conditions. Planting made the establishment of Virginia fanpetals plantations safer, although it incurs some extra costs. Consequently, the production of Virginia fanpetals can be highly economical for farmers farming marginal land with the application of organic manure and with biogas plants in operation. Another option is crop production with a high heat demand, as well as beekeeping activities.

\section{Acknowledgments}

This study and our research work was partly supported by the Ereky Károly Biotechnology Foundation (Debrecen, Hungary). Special thanks to Mihály Dombi, Ph.D., who contributed to our research by translating relevant literature from Polish.

\section{References}

[1] Kessler E. Biofuels, climate change, and human population. Global Economic and Environmental Aspects of Biofuels. 2012:147.

[2] Popp J, Lakner Z, Harangi-Rákos M, Fári M. The effect of bioenergy expansion: Food, energy, and environment. Renewable and Sustainable Energy Reviews. 2014;32:559-78.

[3] Fári MG, Antal G, Kurucz E, Szabolcsy É. Biogenerációs növények kutatása a Debreceni Egyetemen és a magyar agrár-biotechnológiai innováció néhány kitörési pontja (The research of biogeneration plant in the University of Debrecen and the agro-biotechnology breaking points in Hungary). In: Kalmár F, editor. Fenntartható energetika, megújuló energiaforrások optimalizált integrálásával (Sustinable energy by optimalized renewable energy sources) Debrecen: Akadémiai Kiadó; 2014. p. 237-64.

[4] Cai X, Zhang X, Wang D. Land availability for biofuel production. Environmental Science \& Technology. 2010;45:334-9.

[5] Shu K, Schneider U, Scheffran J. Bioenergy and Food Supply: A Spatial-Agent Dynamic Model of Agricultural Land Use for Jiangsu Province in China. Energies. 2015;8:12369.

[6] Bonner I, Cafferty K, Muth D, Tomer M, James D, Porter S, et al. Opportunities for Energy Crop Production Based on Subfield Scale Distribution of Profitability. Energies. 2014;7:6509.

[7] Panoutsou C. Socio-economic impacts of energy crops for heat generation in Northern Greece. Energy Policy. 2007;35:6046-59.

[8] Dombi M, Kuti I, Balogh P. Sustainability assessment of renewable power and heat generation technologies. Energy Policy. 2014;67:264-71.

[9] Canada Go. Recovery Strategy for the Virginia Mallow (Sida hermaphrodita) in Canada. In: Canada Eo, editor. Species at Risk Act Recovery Strategy Series. Ottawa. 2015. p. $21+$ Appendix.

[10] Packa D, Kwiatkowski J, Graban Ł, Lajszner W. Germination and dormancy of Sida hermaphrodita seeds. Seed Science and Technology. 2014;42:1-15.

[11] Borkowska H, Styk B. Sida hermaphrodita. Cultivation and use (Lazowiec pensylwaski. Uprawa i wykorzystanie). Lublin: Wydawnictwo AR; 2006.

[12] Spooner DM, Cusick AW, Hall GF, Baskin JM. Observations on the distribution and ecology of Sida hermaphrodita (L.) Rusby (Malvaceae). Sida contributions to botany. 1985:215-25.

[13] Pszczółkowska A, Romanowska-Duda Z, Pszczółkowski W, Grzesik M, Wysokińska Z. Biomass Production of Selected Energy Plants: Economic Analysis and Logistic Strategies. Comparative Economic Research. 2012;15:77-103. 
[14] Borkowska H, Styk B, Molas R, Vinterbäck J. Virginia fanpetals-huge potential for one of the most promising perennial biomass crops. Proceedings of the World Bioenergy

Conference and Exhibition on Biomass for Energy, Jönköping, Sweden, 27-29 May 2008: Swedish Bioenergy Association; 2008. p. 104-6.

[15] Dolinski R. Influence of treatment with hot water, chemical scarification and storage time on germination of Virginia fanpetals (Sida hermaphrodita (L.) Rusby) seeds.. Hodowli i Aklimatyzacji Roslin. 2009;251:293-303.

[16] Egley GH, R. N. Paul J. Morphological Observations on the Early Imbibition of Water by Sida spinosa (Malvaceae) Seed. American Journal of Botany. 1981;68:1056-65.

[17] Chudzik B, Szczuka E, Domaciuk M, Danail P. The structure of the ovule of Sida hermaphrodita (L.) Rusby after pollination. Acta Agrobotanica. 2010;63:3-11.

[18] Kurucz E, Fári MG. Improvement of germination capacity of Sida hermaphrodita (L.) Rusby by seed priming techniques. International Review of Applied Sciences and Engineering. 2013;4:137-42.

[19] Krzaczek P, Szyszlak J, Zarajczyk J. Assessment of the influence of selected operating parameters of S071/B KRUK seeder on seeding Sida hermaphrodita Rusby seeds. Int Agrophysics. 2006;20:297-300.

[20] Borkowska H, Molas R. Weeding and Virginia mallow plant density depending on herbicides. Annales UMCS, Agricultura. 2008;63.

[21] Davis KM, Kujawski JL. Propagation protocol for production of container Sida hermaphrodita plants (Container plugs). Natural Resources Conservation Service-Norman A Berg National Plant Materials Center, Beltsville, Maryland In: Native Plant Network URL: http://www.nativeplantnetwork.org (accessed 14 May 2015) Moscow (ID): University of Idaho, College of Natural Resources, Forest Research Nursery. 2001.

[22] Wyszkowska J. Effect of Soil Contamination with Treflan 480 EC on Biochemical Properties of Soil. Polish Journal of Environmental Studies. 2002;11: 71-7.

[23] Borkowska H, Molas R. Weeding and Virginia mallow plant density depending on herbicides. Annales Universitatis Mariae Curie. 2008;63:10-6.

[24] Gansberger M, von Gehren P, Pichler W, Wopienka E, Montgomery L, Mayr J. Sida hermaphrodita L. - A promising energy crop for producing an intelligent, densified and versatile energy carrier for Central Europe. 2015. Scientific Poster. Amsterdam, RAI Exhibition and Convertion Centre, 24th EUBC\&E 2016.

[25] Laurent A, Pelzer E, Loyce C, Makowski D. Ranking yields of energy crops: a metaanalysis using direct and indirect comparisons. Renewable and Sustainable Energy Reviews. 2015;46:41-50.

[26] Nabel M, Temperton V, Poorter H, Jablonowski ND. Energy Crop (Sida hermaphrodita) Fertilization using Digestate and Legume Intercropping under Marginal Soil Conditions. 23rd European Biomass Conference and Exhibition. Vienna, Austria. Pflanzenwissenschaften; 2015.

[27] Nabel M, Temperton VM, Poorter H, Lücke A, Jablonowski ND. Energizing marginal soils - The establishment of the energy crop Sida hermaphrodita as dependent on digestate fertilization, NPK, and legume intercropping. Biomass and Bioenergy. 2016;87:9-16.

[28] Šiaudinis G, Jasinskas A, Šarauskis E, Steponavičius D, Karčauskienė D, Liaudanskienė I. The assessment of Virginia mallow (Sida hermaphrodita Rusby) and cup plant (Silphium perfoliatum L.) productivity, physico-mechanical properties and energy expenses. Energy. 2015;93:606-12.

[29] Šiaudinis G, Liaudanskiene I, Slepetiene A. Changes in soil carbon, nitrogen and sulphur content as influenced by liming and nitrogen fertilization of three energy crops. Icelandic Agricultural Sciences. 2017;30:43-50. 
[30] Kuś J, Matyka M. Wybrane elementy agrotechniki roślin uprawianych na cele energetyczne (Selected aspects of the agrotechnology of plants cultivated for energy), In: Bocian P., Golec T., and Rakowski. Nowoczesne technologie pozyskiwania i energetycznego wykorzystania biomasy (Modern technologies for receiving and using biomass for energy). 2010:101-20.

[31] Szyszlak-Bargłowicz J, Zając G, Piekarski W. Energy biomass characteristics of chosen plants. International Agrophysics. 2012;26:175-9.

[32] Borkowska H, Molas R. Two extremely different crops, Salix and Sida, as sources of renewable bioenergy. Biomass and Bioenergy. 2012;36:234-40.

[33] Borkowska H, Molas R, Kupczyk A. Virginia Fanpetals (Sida hermaphrodita Rusby)

Cultivated on Light Soil; Height of Yield and Biomass Productivity. Polish Journal of Environmental Studies. 2009;18:563-8.

[34] Borkowska H, Molas R. Yield comparison of four lignocellulosic perennial energy crop species. Biomass and Bioenergy. 2013;51:145-53.

[35] Szepmlinski W, Parzonka A, Salek T. Yield and energy efficiency of biomass production of some species of plants grown for biogas. Acta Scientiarum Polonorum Agricultura. 2014;13:67-80.

[36] Jablonowski ND, Kollmann T, Nabel M, Damm T, Klose H, Müller M, et al. Valorization of Sida (Sida hermaphrodita) biomass for multiple energy purposes. Gcb Bioenergy. 2017;9:202-14.

[37] Kocon A, Matyka M. Phytoextractive potential of Miscanthus giganteus and Sida hermaphrodita growing under moderate pollution of soil with $\mathrm{Zn}$ and $\mathrm{Pb}$. Journal of Food, Agriculture \& Environment. 2012;10:1253-6.

[38] Słowik T, Szyszlak-Bargłowicz J, Zając G, Piekarski W. Limiting the Environmental Impact of Road Infrastructure through the Use of Roadside Vegetation. Polish Journal of Environmental Studies. 2015;24:1875-1879.

[39] Bogusz A, Oleszczuk P, Dobrowolski R. Application of laboratory prepared and commercially available biochars to adsorption of cadmium, copper and zinc ions from water. Bioresource Technology. 2015;196:540-9.

[40] Ansari A, Gill SS, Gill R, Lanza GR, Newman L. Phytoremediation: Management of Environmental Contaminants: Springer; 2014.

[41] Baran S. Sewage sludge in agro-ecological economy. Zesz Prob Post Nauk Rol. 2004;499:15-20.

[42] Baran S, Oleszczuk P, Żukowska G. Organic waste resources and management in Poland. Selected aspects of organic waste disposal and energy willow biomass production URzeszow, Rzeszów. 2005:17-40.

[43] Kalembasa S, Symanowicz B. Wplyw nawozenia mineralnego, mieszanin osadow posciekowych z kora i trocinami na plonowanie i sklad chemiczny Lolium multiflorum Lam (The effect of mineral fertilisation, sewage sludge mixtures with bark and sawdust on the crop yield and chemical composition of Lolium multiflorum Lam.). Folia Universitatis Agriculturae Stetinensis Agricultura. 1999;77:129-34.

[44] Krzywy E, Iżewska A. Jeżowski 2003: Wpływ komunalnego osadu ściekowego na zmiany niektórych wskaźników żyzności gleby (The impact of municipal sludge on the development of certain indicators of soil fertility). Zesz Probl Post Nauk Rol. 2003:215-23. [45] Kalembasa D, Malinowska E. Wplyw dawek osadu sciekowego na plon i sklad chemiczny trawy Miscanthus sacchariflorus (The effect of sewage sludge doses on the yield and chemical composition of Miscanthus sacchariflorus grass.). Fragmenta Agronomica. 2007;1:113-8.

[46] Wołoszyk C. Agrochemiczna ocena nawożenia kompostami z komunalnych osadów ściekowych i odpadami przemysłowymi (Agrochemical evaluation of fertilizing composts 
with sewage sludge and industrial waste). Rozprawy. Akademia Rolnicza w Szczecinie, 2003;217:1-120.

[47] Maćkowiak C. Wartość nawozowa osadów ściekowych. (The fertilization value of savage sludge.). Inżynieria Ekologiczna (Ecological Engineering). 2001;3:135-45.

[48] Czekała J. Wartość próchnicotwórcza i działanie nawozowe osadu ściekowego (The humus-forming value and the manurial effect of sewage sludge.). Folia Universitatis Agriculturae Stetinensis, Ser Agricultura. 2000;211:75-80.

[49] Czekała J. Chemical properties of compost produced from municipal sewage sludge and various bio-waste. J Res Appl Agric Eng. 2008;53:35-41.

[50] Iżewska A. Przydatność kompostów z komunalnego osadu ściekowego do nawożenia miskanta cukrowego (Miscanthus saccchariflorus (MAXIM.) HACK) (The usefulness of composts from municipal sewagesludge to fertilize the grass Miscanthus sugar miskantusa sacchariftorus). Wydawnictwo Uczelniane Zachodniopomorskiego Uniwersytetu Technologicznego. 2009.

[51] Hargreaves J, Adl M, Warman P. A review of the use of composted municipal solid waste in agriculture. Agriculture, Ecosystems \& Environment. 2008;123:1-14.

[52] Harrison EZ, Oakes SR, Hysell M, Hay A. Organic chemicals in sewage sludges. Science of the total environment. 2006;367:481-97.

[53] Roca-Pérez L, Martínez C, Marcilla P, Boluda R. Composting rice straw with sewage sludge and compost effects on the soil-plant system. Chemosphere. 2009;75:781-7.

[54] Krzywy-Gawrońska E. The effect of industrial wastes and municipal sewage sludge compost on the quality of virginia fanpetals (SIDA HERMAPHRODITA RUSBY) biomass

Part 1. Macroelements content and their upatke dynamics. Polish Journal of Chemical Technology. 2012;14:9-15.

[55] Mocek A, Drzymała S, Maszner P. Genesis, analysis and classification of soils. AR Poznań. 1997:416.

[56] Ociepa E. The effect of fertilization on yielding and heavy metals uptake by maize and Virginia fanpetals (Sida hermaphrodita). Archives of Environmental Protection. 2011;37:1239.

[57] Borkowska H, Wardzinska K. Some effects of Sida hermaphrodita R. cultivation on sewage sludge. Polish Journal of Environmental Studies. 2003;12:119-22.

[58] Grzybek A. Modelling of biomass utilisation for energy purpose. Institute of Technology and Life Sciences, Warszawa. Bioforsk FOKUS 2010;5:135.

[59] Borkowska H, Jackowska I, Piotrowski J, Styk B, Piotrowski J, Styk B. Suitability of cultivation of some perennial plant species on sewage sludge. Polish Journal of Environmental Studies. 2001;10:379-82.

[60] Möller K, Müller T. Effects of anaerobic digestion on digestate nutrient availability and crop growth: a review. Engineering in Life Sciences. 2012;12:242-57.

[61] Nabel M, Barbosa DB, Horsch D, Jablonowski ND. Energy crop (Sida hermaphrodita) fertilization using digestate under marginal soil conditions: A dose-response experiment. Energy Procedia. 2014;59:127-33.

[62] Vaneeckhaute C, Meers E, Michels E, Ghekiere G, Accoe F, Tack F. Closing the nutrient cycle by using bio-digestion waste derivatives as synthetic fertilizer substitutes: A field experiment. Biomass and Bioenergy. 2013;55:175-89.

[63] Walsh JJ, Jones DL, Edwards-Jones G, Williams AP. Replacing inorganic fertilizer with anaerobic digestate may maintain agricultural productivity at less environmental cost. Journal of Plant Nutrition and Soil Science. 2012;175:840-5.

[64] Reeves D. The role of soil organic matter in maintaining soil quality in continuous cropping systems. Soil and Tillage Research. 1997;43:131-67. 
[65] Haraldsen TK, Andersen U, Krogstad T, Sørheim R. Liquid digestate from anaerobic treatment of source-separated household waste as fertilizer to barley. Waste Management \& Research. 2011; 29.12: 1271-1276.

[66] Alburquerque JA, de la Fuente C, Bernal MP. Chemical properties of anaerobic digestates affecting $\mathrm{C}$ and $\mathrm{N}$ dynamics in amended soils. Agriculture, ecosystems \& environment. 2012;160:15-22.

[67] Stolarski MJ, Krzyżaniak M, Śnieg M, Słomińska E, Piórkowski M, Filipkowski R. Thermophysical and chemical properties of perennial energy crops depending on harvest period. International Agrophysics. 2014;28:201-11.

[68] Krička T, Matin A, Bilandžija N, Jurišić V, Antonović A, Voća N, et al. Biomass valorisation of Arundo donax L., Miscanthus $\times$ giganteus and Sida hermaphrodita for biofuel production. International Agrophysics. 2017;31:575-81.

[69] Oleszek M, Matyka M, Lalak J, Tys J, Paprota E. Characterization of Sida hermaphrodita as a feedstock for anaerobic digestion process. Journal of Food, Agriculture \& Environment. 2013;11:1839-41.

[70] Haug RT. The practical handbook of compost engineering: CRC Press; 1993.

[71] Zhang P, Zeng G, Zhang G, Li Y, Zhang B, Fan M. Anaerobic co-digestion of biosolids and organic fraction of municipal solid waste by sequencing batch process. Fuel processing technology. 2008;89:485-9.

[72] Puyuelo B, Ponsá S, Gea T, Sánchez A. Determining C/N ratios for typical organic wastes using biodegradable fractions. Chemosphere. 2011;85:653-9.

[73] Huang Y, Zhang W, Zheng X, Li J, Yu Y. Modeling methane emission from rice paddies with various agricultural practices. Journal of Geophysical Research: Atmospheres. 2004;109. [74] Kurucz E, Antal G, Gábor FM, Popp J. Cost-effective mass propagation of Virginia Fanpetals (Sida hermaphrodita (L.) Rusby) from seeds. Environmental Engineering and Management Journal. 2014;13:2845-52.

[75] McCollum DL, Ogden JM. Techno-economic models for carbon dioxide compression, transport, and storage \& correlations for estimating carbon dioxide density and viscosity. Institute of Transportation Studies. 2006:32.

[76] BloombergMarkets. www.bloomberg.com/energy. 2015. (accessed on 14. 10. 2015)

[77] Pelletexpert. http://pelletexpert.hu/. 2015. (accessed on 14. 10. 2015)

[78] MEKH. Household energy price index for Europe.

http://www.mekh.hu/download/4/ba/10000/HEPI_Press_Release_December_2015.pdf. 2015. (accessed on 20.02.2016)

[79] Dębowski M, Zieliński M, Kisielewska M, Krzemieniewski M. Anaerobic co-digestion of the energy crop Sida hermaphrodita and microalgae biomass for enhanced biogas production. International Journal of Environmental Research. 2017;11:243-50.

[80] Borkowska H, Wróblewska A, Kolasa Z. Sida (Sida hermaphrodita Rusby)-nowa roślina uprawna (Virgina fanpetals (Sida hermaphrodita Rusby)-new cultivated crop). Fragm Agron. $1986 ; 1$.

[81] Mézmester. http://www.mezmester.hu/mez-kisokos/mez_arak. 2015. (accessed on 15. 03. 2016)

[82] Balezentiene L, Streimikiene D, Balezentis T. Fuzzy decision support methodology for sustainable energy crop selection. Renewable and Sustainable Energy Reviews. 2013;17:8393.

[83] Wróblewska H, Komorowicz M, Pawłowski J, Cichy W. Chemical and energetical properties of selected lignocellulosic raw materials. Folia Forestalia Polonica. 2009;40:67-78. [84] Gaur S, Reed TB. An atlas of thermal data for biomass and other fuels. National Renewable Energy Lab., Golden, CO (United States); 1995. 
[85] ZöldtechMagazin. http://zoldtech.hu/cikkek/20150420-tuzeloanyag-felvasarlas. 2015. (accessed on 09. 10. 2015)

[86] BakonyerdőzRT. http://www.bakonyerdo.hu/erdogazdalkodas/fatermekekarjegyzeke/tuzifa. 2015. (accessed on 12. 02. 2016)

[87] Brikettgyár. http://www.brikettgyar.hu/arlista 2015. (accessed on 21. 02. 2016)

[88] Krzyżaniak M, Stolarski MJ, Warmiński K. Life cycle assessment of Virginia mallow production with different fertilisation options. Journal of Cleaner Production. 2018;177:824836.

[89] Pawlak J, Hryniewicz M. Modelling of biomass utilisation for energy purpose. In: Hryniewicz M, editor. Bioforsk 1ed. Norway: Norwegian Institute for Agricultural and Enviromental Research; 2010. p. 135. 